\title{
TESTING THE VIOLATION OF CONSERVATISM ACCOUNTING PRINCIPLE. CASE STUDY ON ROMANIAN LISTED ENTITIES
}

\author{
Ovidiu Constantin BUNGET 1 \\ Eusebiu Răducu BUREANĂ 2
}

DOI: 10.1515/tjeb-2015-0014

\begin{abstract}
From the beginning of the debates regarding the conservatism principle, the concept experienced a significant development. As it is one of the most controversial and violated accounting principle, we started to seek how can we help one of the auditor's challenge in the audit mission: to identify and evaluate the risks from the financial statement level. The most affected accounting principle in Romania is the conservatism principle. After a long time of debates, it was stated that the conservatism principle, considered to be complementary to the "fair view" concept, which means that financial reports shall be required to submit information so impartial and in such a manner as to enable the reader to understand them clearly. Considered as a risk that should be identified, this study demonstrates a relationship between the violation of the conservatism principle and the analysis of the financial indicators, such as: Long-TermDebt-to-Equity Ratio; Debt-to-Equity Ratio; Global Solvency Ratio; Operating Margin Ratio; Current Finance Ratio; Period of Activity Indicator and Auditor Indicator. Based on a quantitative method, this analyze was realized through three econometric model performed on annual financial statements of the companies from Bucharest Stock Exchange. After validating the sample and analyzing the factorial variables, we selected the best model: the probit model. In conclusion, as can be seen in the paper, the econometric function is efficient, reliable and can be applied to assess the risk likelihood for violating the conservatism principle by a Romanian company.
\end{abstract}

Keywords: $\quad$ Conservatism Principle, Econometric Models, Financial and Non-Financial Indicators.

\section{JEL Classification: C12, C52, M40.}

\footnotetext{
${ }^{1}$ Associate Professor, PhD, West University of Timisoara, Timisoara, Romania.

${ }^{2}$ MSc Graduate, West University of Timisoara, Timisoara, Romania.
} 


\section{Introduction}

At national level, the managers' desire to acquire new external loans from lenders and their desire to reduce the tax liability, the Romanian companies fall back on different accounting methods for "modeling” the truth about the financial statements, often resulting in the violation of the accounting principles.

The most controversial accounting principle is undoubtedly the conservatism principle, because it adopts systematically a pessimistic view over commercial transactions. Although the theory of conservatism seems easy in putting it into practice, it raises many questions when dealing with accounting accruals on one hand, and the conservatism principle on the other hand. (Dumitrescu, 2010).

Secondly, the measurement of the conservatism principle is another agent of long debates for decades, when the conservatism principle was firstly stated by academics. (Feleaga \& Feleaga, 2007). For measuring the accounting principles, there were suggested qualitative, quantitative, mathematical or statistical models and recently, even econometric models. Unfortunately, the Romanian studies do not reflect the high level of development regarding the measurement of accounting principles as the international researches does.

Last, but not the least, the reason why this accounting principle is the most controversial, is because when dealing with the reality of our home market, it was demonstrated that the conservatism principle is the most violated principle in the Romanian business market (Bunget \& Dumitrescu, 2012; Bunget et al., 2013). Moreover, conservatism (called "conditional conservative financial information") is exactly what debt and equity holders and corporations' suppliers seek for (Barth \& Landsman, 2010).

As it is still a very debated and important accounting principle, it grew our attention towards contributing to develop a measurement mechanism of the violation of the conservatism principle in Romania.

Beside discovering the factors which give entities a propensity to violate the conservatism principle, this study objective is to construct an additional instrument for the external auditors in detecting if an entity has the risk of affecting this principle.

For constructing the assurance basement of the financial statements, the auditor, in the first phase of his mission, follows the stages of understanding the entity's environment and of gathering general information about the entity (Toma, 2012). As we consider this stage (to understand the entity, the environment and his internal control system, as it is mentioned in ISA 300) an important one, we wanted to dig deeper into this aspect, with the willing to help the 
auditor with a complementary tool besides other procedures it may have: to gather information about the status of the enterprise, to test the control system etc. Thus, in addition to his information about the entity, fiscal regulations and risk factors, we suggest into the same stage, an econometric model which evaluate the risk level of violating this principle.

Because the auditors' responsibility regarding the detection of deliberate errors has been raised, it is necessary to develop new models and new valuation procedures for the risks unrelated with the sampling, procedures that can incorporate variables which may result into deliberate distortions (Domnisoru et al., 2013).

The additional objective of this study is to develop a previous econometric model which was constructed based only on four financial indicators (Bureana \& Bordea, 2014).

In the first part, we sought after some evidences regarding the development of the "conservatism" concept from the last decades. Then, based on the literature review, we found some factors which can detect when entities have propensity to violate the conservatism principle. Studying the correlation between factorial variables and the violation of the conservatism principle, we proposed some hypotheses to be tested. To validate the hypothesis, we used three econometric models (OLS and two binary models - probit and logit) and we find significant relations between the violation of conservatism model and five financial ratios (three solvency ratios, one financial structure ratio and a profitability ratio). Moreover, there is a significant dependency between violating the conservatism principle and the period of activity of entity as well as if the entity is certified by a Big4 or non-Big4.

\section{Delimitations for the "Conservatism" Concept}

Going back in times, conservatism was a debated subjected from the beginning of the XIXth centuries, at the same time with the appearance of the "static accounting" (1800-1900) in the continental Europe (Baker \& Burlaud, 2014). For example, in France, at the beginning of the 19th century, this theory admitted that to determine the financial result of a company, it might be considered both the potential losses and the unfulfilled profits/ latent added values and benefits that arise from these profits which may be distributed as dividends, and in the bankruptcy case, these may be recovered from the entrepreneurs' personal assets. From this point of view, the conservatism principle was not well drawn, Bliss (1924) alleging "the conservatism accounting is described as no profit anticipation, but only losses". Despite of this, afterwards, this theory was modified through the prohibition of the distributing the dividends from unrealized profits (Baker \& Burlaud, 2014).

Likewise, in Germany it was applied Eugen Schmalenbach's "static" theory in which the assets were valued at the market value by taking into consideration the going concern principle, 
according to which it is necessary to anticipate the fall of every entity in the way that it should be liquidated, so it affected the conservatism principle (as it is seen nowadays). A little bit later, in the U.S.A., John Canning (1929) issued a conceptual framework for valuating the assets and the measurement of the results based on anticipations, similarly with the Schmalenbach theory.

The conservatism principle had a major interest in the corporate governance too, especially in the second part of the XXth century in the USA, when the companies' assets succeeded in being held more and more by the employees of the companies; resulting in the increased attention from managers, who started to think more about the "conservatism" and how can it be integrated in their decisions. Thus, on September 1974, the ERISA was issued which extended the definition of fiduciary to encompass a broader class of investment managers and, at the same time, expanded fiduciaries' responsibilities to the portfolios they manage.

Nowadays, to talk about conservatism, firstly, we are obliged to define the concept of "fair view" because the conservatism, which is a complement of the true image, is also the most disputed principle with the objective of the fair view, conflict that never can be eliminated. Fair view is represented by "the image that can be trusted". Being the image that can be given credit to; and this because it was accepted the idea that "there may be more accurate images". This has a higher importance as Barth (2006, p. 98) states that "In almost every standard-setting project of the FASB and IASB, the boards consider fair value as a possible measurement attribute".

Over the years, through the recognized regulators, it was established that conservatism means not to present a very favorable image by ignoring certain facts or events that may have impact on future financial statements. From the Basu (1997) point of view, conservatism is seen as "the accountants' tendency to require a higher degree of verification for recognizing good news than bad news in financial statements". Even though, conservatism principle is omitted from the current international standards, in the Romanian law, it is still a requirement entities should account for when issue the entity's financial position.

\section{Methodology and Hypothesis}

The factors which make an entity to violate the conservatism principle have been object of many studies lately. In choosing the most representative variables which best describe the tendency of the economic agents to violate the accounting principles (in our case the conservative one) there are not many national studies which focus particularly on this. Despite of that, we consider some relevant studies which can support our decision regarding the selection of variables (Jackson \& Wood, 2013; Kothari et al., 2010).

For example, Wang \& Lee (2008) presented a clustering method which identify the most representative financial ratios when dealing with entities performance measurement. They 
Bunget, 0. C. \& Bureana, E. R. (2015). of Economics and Business

Testing the violation of conservatism accounting principle. Case study on Romanian listed entities

choose to partition the financial ratios based on the well-known four categories: Solvency, Profitability, Return on investment, Asset and debt turnover.

According to Bunget and Dumitrescu (2012), the determinants of violating the conservatism principle are: management KPIs strongly related with entity's financial performance; eligibility for attracting external resources from banks or credit institutions or to benefit from fiscal deductions.

Besides the factors that were identified when coming up the discussion about violating conservatism principle, there were also attempts to create specific models which can identify signals when an entity has some propensity to violate this principle. (Gillis, 1977)

Basu (1997) proposes a model for valuating the fair appliance of the conservatism principle by executives. Based on responses that executives give to the market, they influence the fluctuation of market share's prices. Therefore, market prices react at the announcement of good and bad news. Therefore, Basu quantifies good news and bad news through the variation of share prices.

Starting from this study, Toma and Robu (2014) proposed a model (through the variance analysis and linear regression) which verify the appliance of the conservatism principle through the following independent variables: good and bad news announcements and if entities were certified by Big4s. The dependent variable was measured by: Assets Growth Rhythm, Debts Growth Rhythm, Equity Growth Rhythm, Net Income Growth Rhythm and Stock Market Growth Indicator.

The majority of the theoretical and practical materials regarding the deliberate distortions is dealing with deterministic-causal models which measures the influence of separated factors on bad financial scenarios, there are also very limitative models which definitely need periodically improvements. If in the last decades, it was used mathematical and statistical models, nowadays it is used a combination of these: the econometric models.

Econometric models were used for different objectives: for measuring the entities performances (Ganea \& Cârstina, 2013), for delivering supporting information for the manager's decisionmaking (Kothari \& al, 2013), for detecting the fraud risk (Jackson \& Wood, 2013) and when an entity damaged his going concern status. In the same manner, we propose for testing an econometric model which will test the risk of violating the conservative accounting principle. 


\section{Data and Descriptive Statistics}

\subsection{Sample}

The selected population are entities whose financial statements are ensured by the external auditors, based on art. 34, line (1-2), from Law 82/1991 (Romanian Accounting Law), whose assets are commercialized on a regulated market on 12/31/2012 and 12/31/2013.

Thus, we selected the public entities from Bucharest Stock Exchange section (category I, II, III), in total of 158. For the relevance of the data, there were deducted the entities in the banking sectors, insurance and investment funds (13 entities), entities which are in insolvency (7) and those which were considered for the econometric model: 8 (because of the Operating Margin Ratio varied between $-239 \%$ and $-13 \%$ and because of the Global Solvency Ratio which has the value of 11.4). The resulted sample size equals 117. For that, we reviewed the Annual Reports of the external auditors and the results are as follows: 84 had unqualified opinion, 31 qualified opinion, one disclaimer for opinion and one had adverse opinion. From these, there were observed 15 entities which violated the conservatism principle (including the entity with the adverse opinion) and the rest, 102 did not. The entities' activity area is: $72 \%$ in industrial sector, $20 \%$ in services sector and $8 \%$ in the commerce sector.

\subsection{Variables}

For taking the right decision regarding the most appropriate variables, we based our decision on the following facts:

Models regarding the detection of the risk of violating the conservatism principle are mainly the same models as there are to detect the fraud risk. For the latter, the auditor must consider both the financial factors and non-financial factors as it is known that, usually, the risk represent a combination between these (Tole, 2000). For example, even since the half of the XIXth century, there were used Financial indicators for predicting bad scenarios (ex. bankruptcy) such as: Return on assets, Current finance Ratio, Debt-to-assets Ratio and Sales/Total Assets. (Ohlson, 1980, Collins, 1980, Achim et al., 2012, Robu et al., 2012). Also, the studies show that the signals which best "alert" when an entity is indicating financial degradation are mostly debt ratios which represent the inability of the entity to repay its debts, capacity which can be sustained by a good profitability which is correlated with a good financial structure, structure which must be permanently reviewed. In our opinion, these examples may be a good start point for our decision of choosing the right indicators.

International studies demonstrated a growth in the users' vigilance when it comes to financial reporting (Nobes \& Parker, 2008). For choosing the right financial ratios, Wang \& Lee (2008) developed a clustering method to identify the most representative financial ratios for measuring 
Bunget, O. C. \& Bureana, E. R. (2015). of Economics and Business

Testing the violation of conservatism accounting principle. Case study on Romanian listed entities

the financial performances of entities. They chose to classify financial ratios based on the wellknown four categories (stated into accounting classification). Financial ratios across different categories are considered to be unrelated, so these ratios from the same category are clustered together. The categories are presented in Table 1

Table 1. The Four Categories of Financial Ratios

\begin{tabular}{|c|c|c|}
\hline Source & Category & Ratio \\
\hline $\begin{array}{c}\text { Balance } \\
\text { sheet }\end{array}$ & Solvency & $\begin{array}{c}\text { Current ratio } \\
\text { Fixed ratio } \\
\text { Equity ratio } \\
\text { Fixed/long-term ratio } \\
\text { Debt ratio } \\
\text { Equity/debt ratio }\end{array}$ \\
\hline $\begin{array}{c}\text { Income } \\
\text { statement }\end{array}$ & Profitability & $\begin{array}{l}\text { Operation cost ratio } \\
\text { Gross profit ratio } \\
\text { Operation profit ratio } \\
\text { Income before tax ratio } \\
\text { Net income ratio }\end{array}$ \\
\hline $\begin{array}{l}\text { Balance } \\
\text { sheet and } \\
\text { income } \\
\text { statement }\end{array}$ & $\begin{array}{l}\text { Return on } \\
\text { investment }\end{array}$ & $\begin{array}{c}\text { Return on current assets } \\
\text { Return on fixed assets } \\
\text { Return on total assets } \\
\text { Return on stockholder's equity } \\
\text { Return on operation to capital } \\
\text { Return on income before tax to capital }\end{array}$ \\
\hline & $\begin{array}{c}\text { Asset and debt } \\
\text { turnover }\end{array}$ & $\begin{array}{c}\text { Current assets turnover } \\
\text { Fixed assets turnover } \\
\text { Total assets turnover } \\
\text { Stockholder's equity turnover } \\
\text { Current liabilities turnover } \\
\text { Long-term liabilities turnover } \\
\text { Total liabilities turnover }\end{array}$ \\
\hline
\end{tabular}

Source: Wang \& Lee (2008) pp. 1089.

According to this, we selected the financial ratios further presented.

Firstly, we chose three Solvency Ratios. Solvency refers to an enterprise's capacity to meet its long-term financial commitments. As Bueno Campos \& al (1992, p.333) said, choosing the level of debt ratios within an entity is the most important decision regarding the accounting policy of an entity. The most used debt ratios are considered to be: Debt-to-equity ratio and Long-TermDebt-to-Equity Ratio (Manolescu, 2005, p. 386).

The third solvency ratio is Global Solvency Ratio. Another leverage measurement, this ratio measures the percentage of a company's assets that have been financed with debt (short-term 
Testing the violation of conservatism accounting principle. Case study on Romanian listed entities

and long-term debts). A higher ratio indicates a greater degree of leverage, and consequently, financial risk.

Profitability ratios (rates of return) are a relative measure that expresses the degree in which the capital as a whole brings profit. According to Bordeianu (2006), the most used rate of return, among any others, is Operating Margin Ratio. Beside the level of the entity activity expressed by Turnover, this ratio also measures the efficiency of the company through its profit value. The commercial management is the main responsible for this level of activity and the top level management is the main responsible for assuring the efficiency of the overall activity.

The Current Finance Ratio expresses the company's ability to pay back its short-term liabilities (debt and payables) with its short-term assets (cash, inventory, receivables). The higher the current ratio, the more capable the company is of paying its obligations. A ratio below 1 , suggests that the company would be unable to pay off its obligations if they came due at that point. While this shows that the entity do not have a good financial health, it does not necessarily mean that it will go bankrupt - as there are many ways to access resources - but it is definitely not a good sign. It also expresses the efficiency of the operating cycle or its ability to turn the products into cash.

Unfortunately, for all these financial ratios, being given the heterogeneity of the sample and the period of the values within sample we cannot provide optimum values for our study, only values which we can observe in the theory. It also remains a possibility for future research to address this issue.

According to the literature studied and to the arguments stated above, we chose the following group of financial ratios: 3 solvency ratios (Debt-to-Equity Ratio=Total debts/Equity; Global Solvency Ratio $=$ Total Assets/Total Debts and Long-Term-Debt-to-Equity Ratio $=$ Long term Liabilities/Equity), one profitability ratio (Operating Margin Ratio= Operating Results/Return on Sales); a ratio which present the financial structure of the entity (Current finance ratio= Current liabilities/Current Assets).

Besides the financial indicators, we also consider a necessity to add non-financial indicators. The first one is the Chosen Auditor Indicator (which returns "1" when the auditor was a Big4 company and 0 otherwise), this factor is considered as having a direct relation with the conformity grade of the financial statements in terms of IFRS. (Hudgdon et al., 2009; Messier et al., 2008; Comprix et al., 2012, Dima et al., 2013). In the same manner, Hope et al. (2008) demonstrates the existence of one relation between the transparency grade which is correlated with the quality of the entities' financial statements communication and the election of a Big4 or not.

The second non-financial ratio is The period of activity (which records the period since the registration date by now and returns 0 for entites with an activity period of more than 20 years and 1 , otherwise). 
Bunget, O. C. \& Bureana, E. R. (2015). of Economics and Business

Testing the violation of conservatism accounting principle. Case study on Romanian listed entities

Based on the selected indicators, every entity can be classified in one of the two categories: either company having propensity to affect the conservatism principle or company not having propensity.

\subsection{Models}

To test the formulated assumptions, we used 3 methods: the least square method, binary probit method and binary logit method.

Even though probit and logit were not common used on the 1980s articles, with a growing trend, they have become critical parts of the content analysis methodology from nowadays.

The binary logit model is a conditional probability model which uses the non-linear maximum log-likelihood technique to estimate the probability of violating the conservatism principle under the assumption of a logistic distribution. The parameter estimates are obtained using the logit model's maximum likelihood method as derived in Gujarati (2003).

In particular, the logit and probit models neither requires multivariate normally distributed variables, nor they rely on equal variance-covariance matrices of the two classification groups (Ohlson, 1980; Zavgren, 1983). The logit and probit models do, however rely on two basic assumptions: the dependent variable is dichotomous (this means treating conservatism principle violation as being discrete, non-overlapping, therefore not reflecting the true nature of the accounting practices) and the input variables may be chosen arbitrary, these two being therefore the most appropriate models in our case.

The robust covariance estimates were also applied for more accurate results. Besides that, we also used Least Square Method for comparing the previous results. We choose the best method by considering criteria like Akaike info criterion (AIC) or R squared.

The OLS model which analyzes the relation between the affecting of conservatism principle and the seven explanatory variables can take the following linear form:

$$
C=a_{0}+a_{1} \times L T D / E+a_{2} \times D / E+a_{3} \times G S R+a_{4} \times O M R+a_{5} \times C F R+a_{6} \times P A+a_{7} \times C A+\varepsilon
$$

The probit and logit version of the model are non-linear functions.

Where $\mathrm{C}$ is the dependent variable (which records the value 1 when the conservatism principle is affected and 0 otherwise), the model coefficients ao...a7, the independent variables and $\varepsilon$, the residual value. For building the model, we will follow these steps: 
Bunget, 0. C. \& Bureana, E. R. (2015). of Economics and Business

Testing the violation of conservatism accounting principle. Case study on Romanian listed entities

- Testing the significance of the model for the selected sample;

- Testing the causal relation between the independent and dependent variables;

- Testing the parameters of the seven indicators and their analysis from the economic point of view.

\subsection{Descriptive statistics}

Before testing the models, data will be described in order to better understand the variables.

Table 2 presents the summary statistics of the financial data included in the whole sample.

Table 2. Descriptive statistics

\begin{tabular}{lcccc}
\hline \multicolumn{1}{c}{ Variable } & Mean & Std.Dev. & Min & Max \\
\hline Y & 0,128 & 0,336 & 0 & 1 \\
LONG_TERM_DEBT_TO_EQUITY & 0,091 & 1,530 & $-14,980$ & 3,510 \\
DEBT_TO_EQUITY & 0,658 & 2,968 & $-23,530$ & 15,840 \\
GLOBAL_SOLVENCY & 5,856 & 8,155 & 0,630 & 54,680 \\
OPERATING_PROFIT_MARG & 0,033 & 0,207 & $-1,320$ & 0,940 \\
CURRENT_FINANC_RAT & 0,798 & 0,852 & 0,030 & 5,060 \\
PERIOD_OF_ACTIVIT & 0,094 & 0,293 & 0 & 1 \\
CHOSEN_AUDITOR & 0,342 & 0,476 & 0 & 1 \\
\hline Obs with Dep=0 & 102 & & & \\
Obs with Dep=1 & 15 & & & \\
\hline Total & 117 & & & \\
\hline
\end{tabular}

Source: Authors' calculation.

In our sample, only 15 out of 117 (12.8\%) violated the conservatism principle.

Based on a first overview, we can observe a few extreme values, especially on Long-Term-Debtto-Equity Ratio, Debt-to-equity Ratio and Global Solvency Ratio. It is clear that there is heterogeneity within the sample.

The average of Long-term-debt-to-equity Ratio is pretty small. From 2005, when Manolescu stated that the tendency regarding the financing of Romanian companies is to sustain activity more on short-term loans than long term ones, it seems he same trend is being perpetuated. The average value of debt-to-equity ratio is within the optimum value stated in theory. 
Bunget, O. C. \& Bureana, E. R. (2015). of Economics and Business

Testing the violation of conservatism accounting principle. Case study on Romanian listed entities

The Global Solvency Ratio, despite the large standard deviation and the extreme values, has also a high mean value. It could suggest the fact that Romanian entities are investing much capital on assets or they are prudent enough not to finance their activity based on external sources.

The mean value of the non-financial indicators: Period of activity and Chosen Auditor Indicator are low enough, especially the period of activity, being clear that the most of the entities started earlier than 1998 (20 years ago). Also, only one third of the public entities were audited by a Big4 company.

Table 3. Correlations

\begin{tabular}{|c|c|c|c|c|c|c|c|c|}
\hline & $>$ & 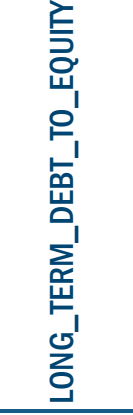 & 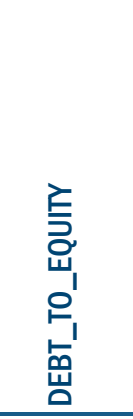 & 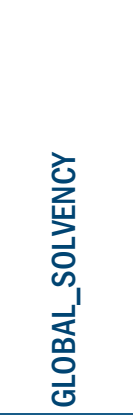 & 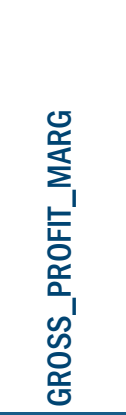 & 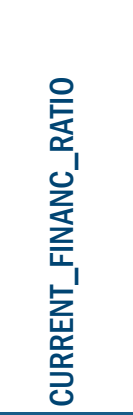 & 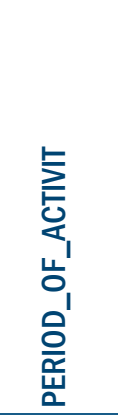 & 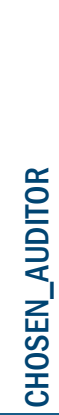 \\
\hline$Y$ & 1 & & & & & & & \\
\hline LONG_TERM_DEBT_TO_EQUITY & -0.181 & 1 & & & & & & \\
\hline DEBT_TO_EQUITY & -0.195 & 0.915 & 1 & & & & & \\
\hline GLOBAL_SOLVENCY & -0.186 & -0.013 & -0.089 & 1 & & & & \\
\hline OPERATING_MARG_RATIO & -0.550 & 0.160 & 0.134 & 0.062 & 1 & & & \\
\hline CURRENT_FINANC_RAT & 0.528 & 0.079 & 0.135 & -0.298 & -0.316 & 1 & & \\
\hline PERIOD_OF_ACTIVIT & -0.036 & 0.007 & -0.039 & 0.036 & 0.176 & -0.082 & 1 & \\
\hline CHOSEN_AUDITOR & 0.155 & -0.131 & -0.128 & -0.162 & -0.122 & 0.106 & 0.200 & 1 \\
\hline
\end{tabular}

Source: Authors' calculation.

Based on Table 3, we can observe that there are no relevant correlations between each individual variables, except the Debt-to-Equity Ratio and Long-term-debt-to-equity Ratio which have a correlation of more than 0.9.Therefore, we decided to exclude the Long-term-debt-toequity Ratio based on the level of significance computed in Table 5. Based on the correlations, we can formulate the following assumptions. 
Testing the violation of conservatism accounting principle. Case study on Romanian listed entities

General Assumption $(H)$ : The test of the violation of conservatism principle can be performed through the analysis of 5 financial indicators and 2 non-financial indicators (Period of Activity Indicator and Chosen Auditor Indicator).

Specific Assumption HL1: The explaining factors: the five financial indicators, the period of the activity of the entity and the chosen auditor represent variables of an econometric model which classifies a listed Romanian entity in one of these two groups.

Specific Assumption HL2: Current Finance Ratio (CFR) and The Chosen Auditor Indicator (CA) have a positive effect on the risk of violating the conservatism principle.

Specific Assumption HL3: Debt-to-Equity Ratio (D/E); The Period of Activity Indicator (PA); Global Solvency Ratio (GSR) and Operating Margin Ratio (OMR) have a negative effect on the risk of violating the conservatism principle.

\section{Empirical Results}

\subsection{Test for the significance of the linear model within the sample size}

In the first step, to test the significance level for the selected sample, we applied Fisher Test, which has been realized with the statistic instrument "F-Test Two Sample for Variances" (alpha $=0.05$ ) with Excel's tools.

$\mathrm{HO}$ - both groups of data regarding the both categories of entities (conservatism principle is or is not violated) present an equal standard deviation. Thus, the sample is not relevant for applying an econometric model on it. F is a ratio between these 2 variation's group) and $P$ indicator assess if there is a probability that the variances of two populations be equal. The results are as follows:

Table 4. Fisher Test applied on the two groups of the sample

\begin{tabular}{cccc}
\hline Indicator & Computed F vs. F critic & The value of P & Ho validation \\
\hline Debt-to-Equity Ratio (D/E) & $\mathrm{F}(12.92)>\mathrm{F}_{\text {critic }}(1.79)$ & $7.81 * 10^{-17}$ & $\mathrm{H}_{0}-$ invalid \\
Global Solvency Ratio (GSR) & $\mathrm{F}(49.61)>\mathrm{F}_{\text {critic }}(2.18)$ & $2.86 * 10^{-10}$ & $\mathrm{H}_{0}-$ invalid \\
Operating Margin Ratio (OMR) & $\mathrm{F}(7.33)>\mathrm{F}_{\text {critic }}(1.79)$ & $2.60 * 10^{-10}$ & $\mathrm{H}_{0}-$ invalid \\
Current Finance Ratio (CFR) & $\mathrm{F}(11.60)>\mathrm{F}_{\text {critic }}(1.79)$ & $1.91 * 10^{-15}$ & $\mathrm{H}_{0}-$ invalid \\
The Period of Activity (PA) & $\mathrm{F}(0.72)>\mathrm{F}_{\text {critic }}(0.55)$ & 0.17 & $\mathrm{H}_{0}-$ invalid \\
The Chosen Auditor (CA) & $\mathrm{F}(0.81)>\mathrm{F}_{\text {critic }}(0.55)$ & 0.26 & $\mathrm{H}_{0}-$ invalid \\
\hline
\end{tabular}

Source: Author's calculations.

Timisoara Journal of Economics and Business | ISSN: 2286-0991 | www.tjeb.ro Year 2015 | Volume 8 | Issue 2 | Pages: 183-202 
Bunget, O. C. \& Bureana, E. R. (2015). of Economics and Business

Testing the violation of conservatism accounting principle. Case study on Romanian listed entities

In all cases, $\mathrm{F}$ is higher than $\mathrm{F}_{\text {critic. }}$ Moreover, in all cases, $\mathrm{P}$ is under the nominator (with a maximum of 0.26) and tends to 0 . The bigger difference for the last 2 indicators is due to the fact that these are dummy, but valued like the other ones from the model. Therefore, these two indicators are more likely to have errors in their estimations. Thus, the entities' values of this indicator which violated the conservatism principle are significantly different compared with entities' values which did not violate the principle on 2012 and 2013.

\subsection{Test for the significance of the linear model within the sample size}

Table 5. Comparative models analysis

\begin{tabular}{cccc}
\hline Variable & Logit & Probit & OLS \\
\hline LONG_TERM_DEBT_TO_EQUITY & $3.725 * *$ & $1.911 * * *$ & $0.045^{*}$ \\
DEBT_TO_EQUITY & {$[1.947]$} & {$[0.944]$} & {$[0.038]$} \\
GLOBAL_SOLVENCY & $-2.163 * *$ & $-1.113 * * *$ & $-0.044 * * *$ \\
& {$[1.119]$} & {$[0.546]$} & {$[0.02]$} \\
OPERATING_MARG_RATIO & $-0.788^{*}$ & $-0.410 * *$ & -0.003 \\
& {$[0.413]$} & {$[0.181]$} & {$[0.003]$} \\
CURRENT_FINANC_RAT & $-21.740 * * *$ & $-12.092 * *$ & $-0.648 * * *$ \\
& {$[6.063]$} & {$[3.076]$} & {$[0.121]$} \\
PERIOD_OF_ACTIVIT & $1.358 *$ & $0.700 * *$ & $0.166 * * *$ \\
& {$[0.727]$} & {$[0.325]$} & {$[0.03]$} \\
CHOSEN_AUDITOR & $-6.071 *$ & $-3.028 *$ & 0.059 \\
& {$[3.190]$} & {$[1.580]$} & {$[0.082]$} \\
Const & -1.137 & $-0.715 *$ & 0.013 \\
S.E. of regression & {$[0.777]$} & {$[0.427]$} & {$[0.050]$} \\
Akaike info criterion & 0.632 & 0.293 & 0.049 \\
F-test & {$[1.345]$} & {$[0.703]$} & {$[0.047]$} \\
\hline McFadden R-squared & 0.625 & 0.627 & 0.494 \\
& 0.208 & 0.211 & 0.246 \\
\hline
\end{tabular}

$\star, * *, * * *$ Significant at 90\%, 95\% and 99\% level, respectively. Standard errors are in parenthesis.

Source: Author's calculations.

The results are as follows.

Coefficients. As the coefficients of probit and logit models cannot be directly compared to those of the OLS model, we resume our discussion only to the statistical validation of the coefficients. As we see, in all models, all the variables are statistically significant (90\%, 95\% and 99\%), except for the Chosen Auditor Indicator for the logit model and Global Solvency Ratio, Period of Activity, Chosen Auditor for OLS model. 
Bunget, O. C. \& Bureana, E. R. (2015). of Economics and Business

Testing the violation of conservatism accounting principle. Case study on Romanian listed entities

Statistical validation of the model. This analysis demonstrates if there is any linear dependence (for OLS model) and non-linear dependence (for probit and logit model) between the variables on the right hand side of the model and the violation of the conservatism principle. The test check whether the null hypothesis of no relation holds true. The resulting value of the F statistic ( 56.015 for logit model; 56.220 for probit and 15.190 for OLS model) is higher than the critical value Fcritical (1.35) at the 0.05 level of confidence. Therefore, the null hypothesis of no relation is rejected.

Graphics. To have a more comprehensive view upon the three models, it was obtained a graph showing the predicted values of $Y$ against the actual one as well as their residuals.

As can be seen both in Figure 1 and Figure 2, probit and logit models, have the same prediction of $Y$ and the residuals are more or less the same. We can observe a few large $Y$ deviations of $\sim 0.8$ out of 1 . We do not know the reasons of these deviations. The only known fact is that all these model errors occurred upon 2013 indicator's values.
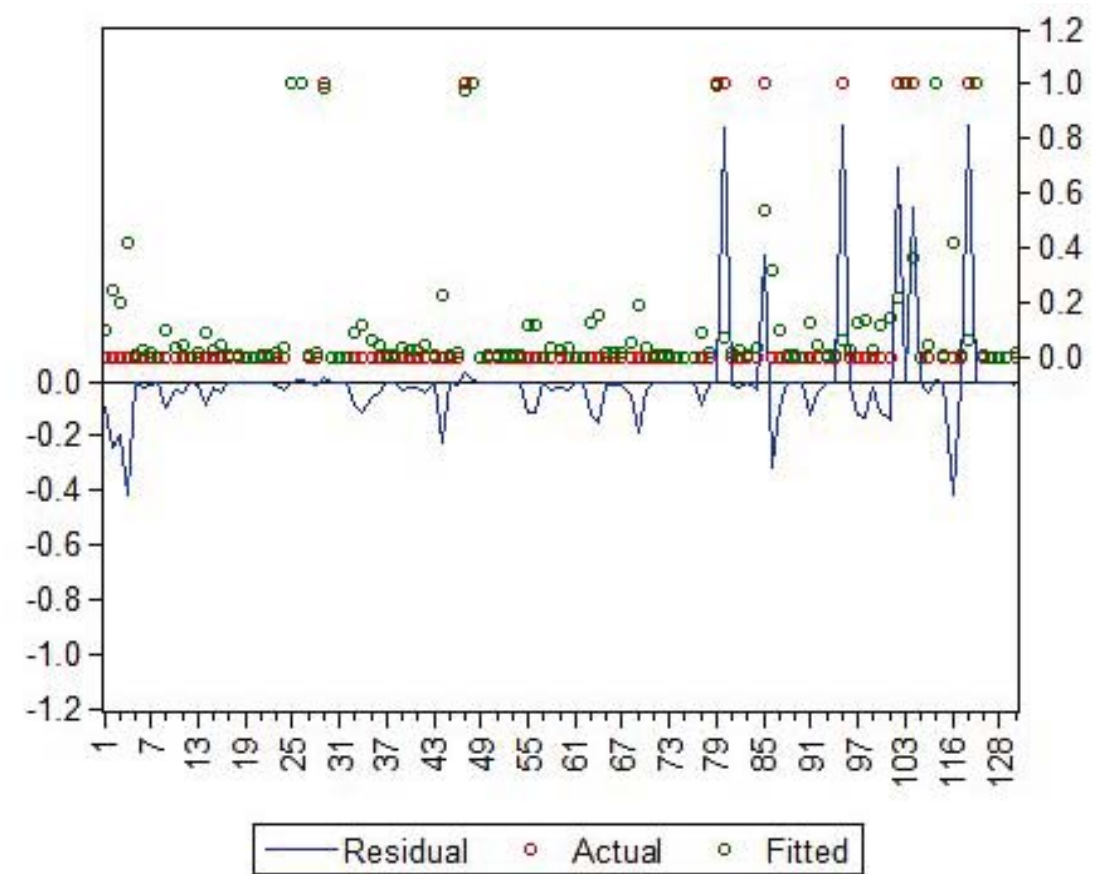

Figure 1. The graph for Binary Logit Model

Source: Own preparation. 
Bunget, O. C. \& Bureana, E. R. (2015). of Economics and Business

Testing the violation of conservatism accounting principle. Case study on Romanian listed entities

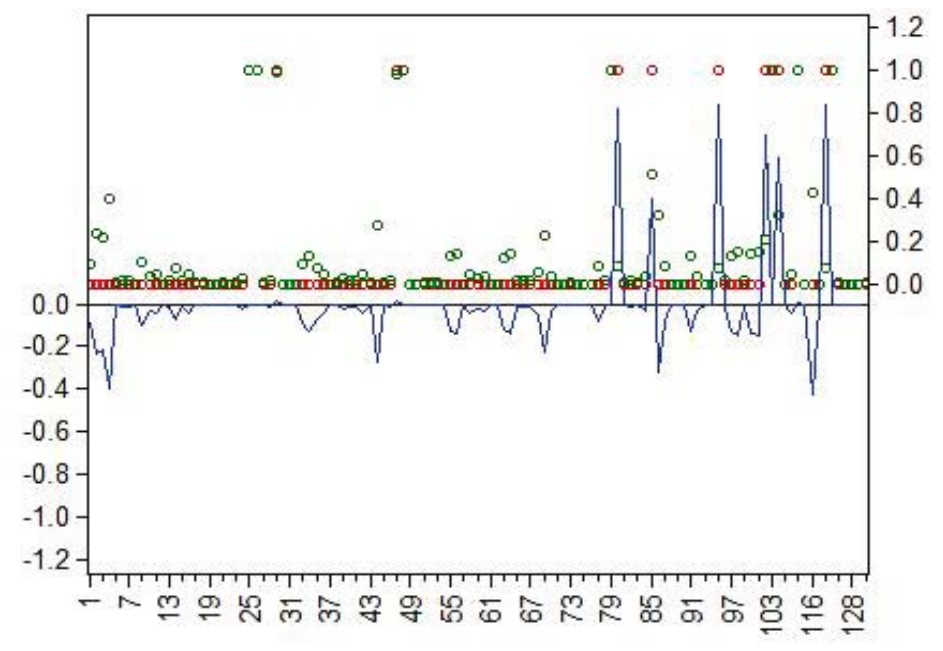

Figure 2. The graph for Binary Probit model

- Residual $\circ$ Actual $\circ$ Fitted

Source: Own preparation.

When comparing the probit and logit models with OLS model (Figure 3), it is obvious that the latter is less accurate and more likely to generate future errors. The same big positive deviations are seen on 2013 indicator's values. Moreover, the interval of residual line plot is [-0.2; 0.2]. So, from the graphical point of view, OLS model is not the best choice. Logit and probit are more accurate.

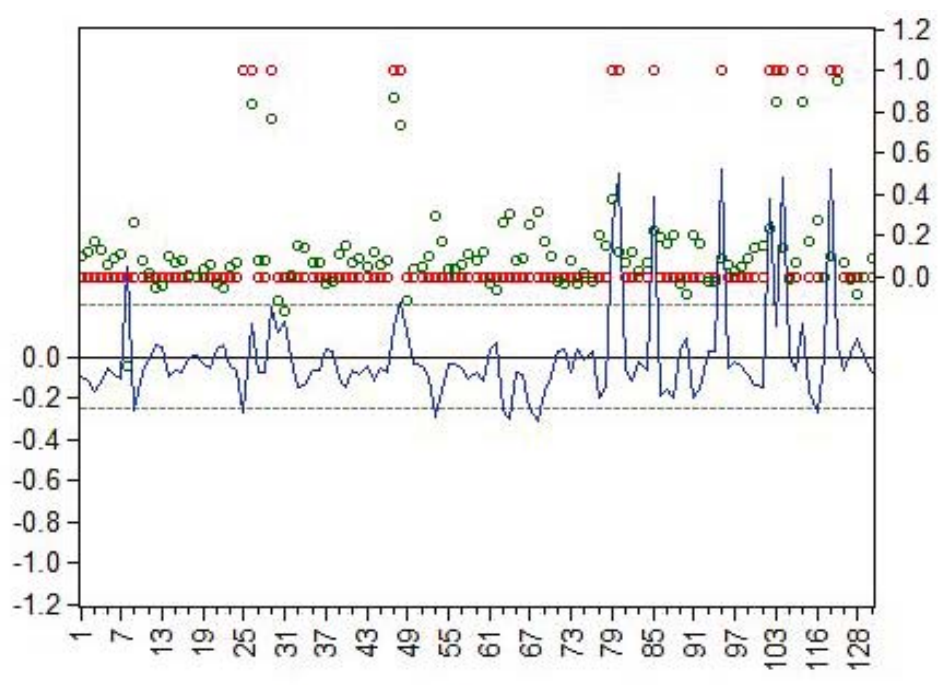

Figure 3. The graph for OLS Model

- Residual $\circ$ Actual $\circ$ Fitted

Source: Own preparation.

DE GRUYTER

OPEN
Timisoara Journal of Economics and Business | ISSN: 2286-0991 | www.tjeb.ro

Year 2015 | Volume 8 | Issue 2 | Pages: 183-202 
Bunget, O. C. \& Bureana, E. R. (2015). of Economics and Business

Testing the violation of conservatism accounting principle. Case study on Romanian listed entities

\section{Measures of model fit}

Because all the models, are statistically correct, we have to select the best model. The first and principal criterion is McFadden R-squared test, as it is the most recommended one (Hoetker, 2007). In OLS regressions, it is common to provide a measure of how well the model has been designed. Unfortunately, no direct equivalent to $\mathrm{R}^{2}$ exists. Even if there are still long lasting debates regarding the comparing of the probit and logit models and OLS model, for this study we consider as adequate comparing the McFadden R-squared. The value of $\mathrm{R}$ square means that $62.5 \%$; $62.7 \%$; $49.4 \%$ respectively, off the variation of the dependent variable is due to the influence of the seven variables and the rest being due to other factors $(\mathcal{E})$. Based on this criterion, the best model is the probit model, even if only marginally outperforming the logit one.

Based on the AIC criterion, the smallest value is registered by the regression model $(0.291$ in spite of 0.613 ; 0.611); so, we should choose the linear regression.

All in all, as we stated in the beginning, our main criterion remain the McFadden R-squared test, so our final model is the probit model, being also the model with the highest level of significant coefficients, even if at the confidence level: 0.1.

For future research, it remains opened the measure of model fit through methods like "correct predictions" (scaling the percentage of correct predictions) or better identification of specific pseudo-R ${ }^{2}$.

\section{Estimation and interpretation of the coefficients}

For interpreting correctly the coefficients of probit model, we should compute the variables' marginal effect. Even if researchers often merely report on the significance level and the sign of logit and probit coefficients, it is more adequate for the probit model to discuss the magnitude of the variables' marginal effect, interaction effect, comparing coefficients across groups or odds ratios (Hoetker, 2007). An equivalent of OLS coefficients is the Variables' marginal effect.

Therefore, we will compute only the marginal effect. For doing this, we used the Eviews programming language, following the steps below.

From our estimated equation, we forecast/choose Index. This created the XB series with values for each entity in our forecast sample. Then we computed the mean of the series, then, the marginal effects weighting term which we multiplied by each probit coefficient and found the variables' marginal effect. We agree that this method is only for continuous variables, but as we consider also relevant for our two dummy variables (non-financial indicators), we keep this method for all our seven variables.

After the previous tests, the coefficients are:

$$
a_{2}=-0.002 ; a_{3}=-0.005 ; a_{4}=-0.28 ; a_{5}=0.035 ; a_{6}=0.0004 ; a_{7}=0.006
$$


We can observe that between the resulting variable and Current Finance Ratio \& two nonfinancial indicators, there is a positive relation. This means an increase in the short debt of the entity will further increase the likelihood of issuing a more favorable financial view of the company as it is closely observed by the creditors. This assumption is strengthened by Watts \& Zimmerman (1990): "the higher the firm debt/equity ratio, the more likely managers use accounting methods that increased income" and Fields et al. (2001)". In general, researchers conclude that their results suggest that "managers select accounting methods to increase their compensation and to reduce the likelihood of bond covenant violations". This is not the demonstration of the Demaria \& Dufour (2007) for a French Sample of firms in which Financial Leverage wasn't linked to fair value adoption.

The negative relation is on Debt-to-Equity Ratio; Global Solvency Ratio and Operating Margin Ratio. An increase in the level of indebtedness in respect with the level of equity, makes the entity much more likely to violate the conservatism principle. A decrease in the overall level of indebtedness in respect with the total assets or an increase in the level of assets in respect to the level of total debt will make the entity more susceptible to violate the conservatism principle. Operation Margin Ratio has the opposite relation in respect with our expectation. The more profitable an entity is, the more likely it is to violate the conservatism principle. About the period of activity, according to the notation of the dummy variable the meaning is that the smaller the entity period of activity is (the indicator tends to 1), the higher the likelihood of following the accounting rules is. Moreover, when an entity is certified by a Big4, the likelihood of issuing a qualified opinion because of the violation of conservatism principle will increase.

\section{Comparison with Previous Model}

All in all, if we compare the current probit model and the previous linear model which was developed on four financial indicators only (Bureana \& Bordea, 2014), we observe an improvement regarding the McFadden R-squared $(0.627$ compared with 0.51 - regression model). Also, standard error of probit model is a little bit smaller than the previous OLS model (0.211 compared with 0.267). As we expected, the higher the sample size is, the smaller the standard errors. The probit model proves to be more fitted to our relation.

\section{Conclusions, Limitations and Perspectives}

The general assumption was validated, except the followings.

The violation of the conservatism principle can be evaluated with four financial ratios (Debt-toEquity Ratio; Global Solvency Ratio; Operating Margin Ratio; Current Finance Ratio) and two non-financial indicators (Period of Activity Indicator and Chosen Auditor Indicator). (H) 
Based on the statistical results obtained, these four financial ratios (Debt-to-Equity Ratio; Operating Margin Ratio; Global Solvency Ratio; Current Finance Ratio) and Chosen Auditor Indicator and Period of Activity Indicator are factorial variables of an econometric model (probit) which classifies a listed Romanian entity in one of the two groups (having propensity to violate the conservatism principle or not having propensity to violate the conservatism principle). $\left(\boldsymbol{H}_{L 1}\right)$

Current Finance Ratio and Chosen Auditor Indicator are directly proportional with the risk level of violating the conservatism principle $\left(\boldsymbol{H}_{L 2}\right)$.

Based on the sample, The Global Solvency Ratio is the most relevant factor of the conservatism principle violation. Beside this ratio, Debt-to-equity Ratio, Operating Margin Ratio validated $\boldsymbol{H}_{L 3}$ by presenting an inversely proportional relation with the risk level of violating the conservatism principle. Beside these ratios, Period of Activity Indicator is directly proportional with the dependent variable, invalidating our hypothesis.

It should be mentioned that the efficiency of the econometric models depends on some restrictions that should be considered when building such a model. Thus, both should be considered, the economic environment of a country or of a region the model was created for and the period, requiring a continuous review of both the indicators and the sample used. Also, another important limit for the econometric model is the normalization system, as it could reflect differences on the financial indicators.

Basically, the set of limits is due to the small sample size of the entities which were considered in the analysis, then due to the small period of time - only two financial years and due to the level of development regarding the economic environment, which has a few deficiencies: the high volatility of the ratios; often fiscal regulation changes; political instability and so forth.

For a relevant result of the model, we should exclude the anomalies (negative debt ratios and high negative values of Operating Margin Ratio) and we should consider the period the model was created for and the economic environment the model was based on (Romania). With these restrictions in mind, this model proves to be an efficient, innovative and developed instrument for the independent auditor in his process of evaluating the risk for conservatism principle violation.

In the future, the analysis can be improved by considering more factors, such as liquidity ratios or cash ratios and by analyzing if there are any signs of clustering effect regarding the entities' activity area. And there can also be performed other types of statistical and econometric models to see if this relation can be better understood. 


\section{Acknowledgements:}

The authors would like to acknowledge to Professor Enrico Rettore, of the Faculty of Economics and Political Science at University of Padua, Italy, as the second reader of this article, and we are gratefully indebted to him for his very valuable comments on this article.

\section{References}

Achim, M.-V., Mare, C., \& Borlea, S.-N. (2012). A Statistical Model of Financial Risk Bankruptcy Applied for Romanian Manufacturing Industry. Procedia Economics and Finance, Volume 3, 132-137

Baker, C.-R., \& Burlaud, A. (2014). From Accounting Theory To Conceptual Framework. Audit Financiar Journal, Year XII, No. 116, 8, 49-62

Barth, M.-E. (2006). Including Estimates Of The Future In Today's Financial Statements. Accounting Horizons, 20, 271-285.

Barth, M.-E., \& Landsman, W.-R. (2010). How Did Financial Reporting Contribute To The Financial Crisis?. European Accounting Review, 19(3), 399-423.

Basu, S. (1997). The Conservatism Principle And The Asymmetric Timeliness Of Earnings. Journal Of Accounting And Economics, 24(1), 3-37.

Bliss, J. -H. (1924). Management Through Accounts. New York: The Ronald Press Co.

Bordeianu, S. (2006). Diagnostic Analysis Based On Rentabilities. Annales Universitatis Apulensis Series Oeconomica, 8(2).

Bueno C.-E., Cruz R.-I., \& Duràn H.-J. (1992). Economica de la empresa. Analisis de las decisions empresariales. Madrid: Ed. Piràmide, S.A.

Bunget, C.-O., \& Dumitrescu, A. (2012). Study On The Relation Between The Audit Opinion And The Esteeming Of Accounting Principles. Audit Financiar Journal, Year X, no. 85, 1, 6-12.

Bunget, C.-O., Dumitrescu, A., \& Deliu, D. (2013). The Manipulation And Truncation Of Accounting Information And The Impact On The Decisional Process Of The Stakeholders. Annals. Economics Science Series. Timisoara, XIX , 84-96.

Bureana, R.-E., \& Bordea, R.-A. (2014). Applicative Model with Regard to Testing the Risk of Affecting the Prudence Principle for Romanian Listed Companies. Audit Financiar Journal, Year XII, no. 118, 10, 13-22.

Collins, W., \& Hopwood, W.-S. (1980). A Multivariate Analysis Of Annual Earnings Forecasts Generated From Quarterly Forecasts Of Financial Analysis And Univariate Time-Series Models. Journal of Accounting Research, $390-406$.

Comprix, J., Muller, K. A., \& Sinclair, J. (2012). Mandatory Accounting Requirements and Demand for Big Four Auditors: evidence from IFRS Adoption in the EU. MEAFA. Retrieved from http://sydney.edu.au/business/_data/assets/pdf_file/0003/121764/Muller_MEAFA_2012.pdf.

Demaria, S., \& Dufour, D. (2007). First Time Adoption Of IFRS, Fair Value Option, Conservatism: Evidences From French Listed Companies. 30 eme colloque de I'EAA, April.

Dima, M., Dima, B., \& Farcane, N. (2013). Determinants of Financial Auditor Choice for the Entities Listed on Bucharest Stock Exchange. Audit Financiar Journal, Year XI, No. 99, 3, 18-28.

Domnisoru, S., Buziernescu, R., \& Roman, A. (2013). A Model For Configuring The Potential Of Modeling The Published Corporative Information. Audit Financiar Journal, Year XI, No. 99, 3, 3-17.

Dumitrescu, A. (2010). The Detection Of Frauds And Errors Within The Financial Audit Process. PhD Thesis, West University of Timisoara.

DE GRUYTER OPEN
Timisoara Journal of Economics and Business | ISSN: 2286-0991 | www.tjeb.ro Year 2015 | Volume 8 | Issue 2 | Pages: 183-202 
Testing the violation of conservatism accounting principle. Case study on Romanian listed entities

Feleagă, L., \& Feleagă, N. (2007). Financial Accounting - An European and International Approach, second edition, Volume 1. Bucharest: Economics Publishing.

Fields, T., Lys, T., \& Vincent, L. (2001). Empirical Research On Accounting Choice. Journal Of Accounting And Economics, 31, 255-307.

Ganea, M., \& Cârstina, S. (2013). Econometric Model to Quantify the Performance of Romanian Enterprises, Audit Financiar Journal, Year XI, No. 106, 10, 46-57.

Gillis, G.-J. (1977). Measurement Of Prudence - Securities And Regulation. Financial Analysts Journal, 33(1), 8-35.

Gujarati, D.-N. (2003). Basic econometrics, United States: McGraw-Hill International Editions: Economic Series.

Hoetker, G. (2007). The Use Of Logit And Probit Models In Strategic Management Research: Critical Issues. Strategic Management Journal, 28, February, 331 - 343

Hope, O.-K., Kang, T., Thomas, W., \& Yoo, Y.-K. (2008). Culture And Auditor Choice: A Test Of The Secrecy Hypothesis. Journal Of Accounting Public Policy, 27, 357-373.

Jackson, R. H.-G., \& Wood, A.-J. (2013). The Performance Of Insolvency Prediction And Credit Risk Models In The UK: A Comparative Study. The British Accounting Review, 45(3), 183 - 202.

Kothari, S.-P., Ramanna, K., \& Skinner, D.-J. (2010). Implications for GAAP from an Analysis of Positive Research in Accounting. Journal Of Accounting And Economics, 50(2-3), 246-286.

Ohlson, J.-A. (1980). Financial Ratios and the Probabilistic Prediction of Bankruptcy. Journal Of Accounting Research, 18(1), 109-131.

Manolescu, I (2005). Estimating Optimal Ratio Of Indebtedness In An Instable Environment. Scientific Annals Of "Alexandru loan Cuza" University Of Iasi, L/LI, 685-690.

Messier, W.-F., Glover, S.-M., \& Prawitt, D.-F. (2008). Auditing and Assurance Services A Systematic Approach. 5th Ed., New York: McGraw Hill Irwin.

Nobes, C., \& Parker, R. (2008). Comparative International Accounting. $10^{\text {th }}$ edition. Essex: Prentice Hall Financial Times.

Robu, B., Robu, M., \& Mironiuc, M. (2012). A Practical Model for Testing the "Going-Concern" Assumption in the Financial Audit Engagement for Romanian Quoted Companies. Audit Financiar Journal. Year X, no. 86, 2, 3-16.

Tole, M. (2000). Entities Financial Analysis. Bucharest: Foundation of Tomorrow Romania Publishing.

Toma, M. (2012). Initiation In Financial Audit For A Entity, $4^{\text {th }}$ Edition, revised. Bucharest: C.E.C.C.A.R. Publishing.

Toma, C., \& Robu. I. B. (2014). Study on the Role of Financial Auditing to Ensure the Conservatism in Financial Reporting, Audit Financiar Journal, 117(9), 3-16.

Watts, R., \& Zimmerman, J. (1990). Positive Accounting Theory: A Ten Year Perspective. The Accounting Review, 65(1), $131-156$.

Wang, Y.-J., \& Lee, H.-S. (2008). A Clustering Method To Identify Representative Financial Ratios. Information Sciences, 178(4), 1087 - 1097.

Zavgren C. (1983). The Prediction of Corporate Failure: The State of the Art, Journal of Accounting Literature,2, 1-38. 